\title{
Cikkismertetés: Az egészség és az egészségegyenlőtlenség makrogazdasági meghatározói - átfogó összegzés
}

\author{
Article review: Macroeconomic determinants of health and health \\ inequalities - an umbrella review
}

Ismertető: $\quad$ Vitrai József $\square$

Ismertetett cikk: Naik, Y., Baker, P., Ismail, S.A. et al. Going upstream - an umbrella review of the macroeconomic determinants of health and health inequalities. BMC Public Health 19, 1678 (2019). https://doi.org/10.1186/s12889-019-7895-6

Beküldve: $\quad$ 2020. 07.19.

doi: $\quad$ 10.24365/ef.v61i4.621

Kulcsszavak: makrogazdaság; egészségmeghatározó tényezők; egészségegyenlőtlenségek

Keywords: macroeconomics; health determinants; health inequalities

\section{HÁTTÉR}

Az egészség társadalmi meghatározói széles körben elismertek, de továbbra sem világos, hogy mi alkotja az egészség makrogazdasági meghatározóit, és mit lehet tenni ezek kezelése érdekében. A témában már korábban megjelent szisztematikus áttekintések átfogó összegzését (umbrella review) végezték el a szerzők a népességszintű makrogazdasági tényezők, stratégiák, szakpolitikák és beavatkozások egészségre és az egészségegyenlőtlenségekre gyakorolt hatásának azonosításához.

\section{MÓDSZEREK}

Kilenc szakirodalmi adatbázisban a „Hatásokra vonatkozó áttekintések összefoglalóinak adatbázisa" (Database of Abstracts of Reviews of Effects; $D A R E)$ kritériumai szerint és egy új koncepciót alkalmazva keresték meg a szerzők a szisztematikus áttekintéseket. A szisztematikus áttekintések minő- ségét standard módszer segítségével értékelték, majd elkészítették az eredményül kapott megállapítások leíró összefoglalását.

\section{EREDMÉNYEK}

Az átfogó összegzés sok ( $\mathrm{n}=62$ ) szisztematikus áttekintésre terjed ki, bár azokban többnyire gyenge minőségú bizonyítékokat lehetett fellelni. Az eredmények azt mutatták, hogy a foglalkoztatás növelése és a munkakörülmények kedvező irányú módosítása hozzájárulhatnak az egészség javításához és a nemek közti egészségegyenlőtlenségek csökkentéséhez. A bizonyítékok arra utalnak, hogy a dohány, az alkohol és az élelmiszerek piaci szabályozása - ideértve az erős adóztatást, illetve a reklámok és a hozzáférés korlátozását - valószínűleg hatékonyan javítja az egészségmutatókat, és csökkenti az egészségegyenlőtlenségeket. A közüzemek és alkoholágazat privatizációja, a jövedelmi egyenlőtlenségek és a gazdasági válságok minden 
bizonnyal növelik az egészség terén mutatkozó egyenlőtlenségeket. Az inkább baloldali kormányok és a jóléti állam gondoskodása az egészségre pozitívan hathat, de a konkrét jóléti beavatkozásokra vonatkozó bizonyítékok nem egyértelműek. A kereskedelem és kereskedelmi szakpolitikák vegyes hatást fejtenek ki. Nem találtak szisztematikus áttekintést a pénzügyi politika vagy a nagy gazdasági intézmények, például a központi bankok és a szabályozó hatóságok egészségre gyakorolt hatásairól.

\section{TANULSÁGOK A HAZAI SZAKEMBEREK SZÁMÁRA}

A megromlott egészség és az országban sokfelé tapasztalható egészségegyenlőtlenségek magyarázatához az egyéni felelősség túlzott hangsúlyozása helyett a társadalmi és a makrogazdasági okokat érdemes figyelembe venni.

\section{KÖVETKEZTETÉSEK}

E tanulmány eredményei egyszerū, mégis átfogó keretet biztosítanak a politikai döntéshozók és a gyakorlati szakemberek támogatására az egészséget befolyásoló makroökonómiai tényezők kezelésében. További kutatásokra van szükség az alacsony és közepes jövedelmű országokra vonatkozóan, és az azonosított, kulcsfontosságú hiányosságokra utaló bizonyítékok összegzése érdekében. 